\title{
RIGHT OF ACCESS UNDER GDPR AND COPYRIGHT
}

by

ANGELA SOBOLČIAKOVÁ*

The paper discusses the right to obtain a copy of personal data based on the access right guaranteed in Articles 15 (3) and limited in 15 (4) of the GDPR. Main question is to what extent the access right provided to data subject under the data protection rules is compatible with copyright. We argue that the subject matter of Article 15 (3) of the GDPR - copy of personal data - may infringe copyright protection of third parties but not a copyright protection attributed to the data controllers.

Firstly, because the right of access and copyright may be in certain circumstances incompatible. Secondly, the data controllers are primarily responsible for balancing conflicting rights and neutral balancing exercise could only be applied by the Data Protection Authorities. Thirdly, the case law of the CJEU regarding this issue will need to be developed because the copy as a result of access right may be considered as a new element in data protection law.

\section{KEY WORDS}

Balancing of Interests and Rights; Computer Program Directive, Copy of the Personal Data Undergoing Processing, Copyright, Database Directive, Data Controller, Data Protection Directive, Data Subject, General Data Protection Regulation, Right of Access

\section{INTRODUCTION}

Nowadays, the life of almost every natural person is lived simultaneously online and offline. The technological development of information society

angelasobolciakova@gmail.com, external Ph.D. student at the Trnava University in Trnava, Law Faculty, Slovak Republic. 
increases the value of personal data and allows for easy traceability of online behaviour of persons, in comparison with their offline life. Therefore, localisation and control over the personal data by data subjects is necessary. In order to improve the position of data subject vis-à-vis data controllers, the data protection legislation developed the right of access by data subject. This right is binding for data controllers and enhances transparency of personal data processing, especially as data controllers have exclusive control over the processing operations. In other words, the right of access

"effectively obliges organizations based anywhere in European Union to provide a copy of all personal data to relevant individual, upon a request being received from such individual."1

The right of access is guaranteed to every natural person and the obligation to comply with the request is entitled to data controllers.

More specifically, this article discusses the obligation of data controller to provide a copy of processed personal data about a data subject upon request. This is a new element in the area of the right of access introduced by the General Data Protection Regulation (hereinafter "GDPR") 2 . Accordingly, this paper will discuss if, and to what extent, the access right provided to data subject under the data protection rules might conflict with copyright.

When reading this article, you need to take into account the following aspects:

First, protection of personal data is regulated through sector specific legislation previously by the Data Protection Directive ${ }^{3}$ (hereinafter "DPD") which was replaced in May 2018 by the GDPR. The processing operations with data are solely in the power of data controllers. Therefore, the copy of processed personal data based on the right of access is created from

1 Carey, P. (2009) Data Protection, A Practical Guide to UK and EU Law. 3rd ed. New York: Oxford University Press.

2 Regulation (EU) 2016/679 of the European Parliament and of the Council of 27 April 2017 on the protection of natural persons with regard to the processing of personal data and on the free movement of such data, and repealing Directive 95/46/EC. Official Journal of the European Union (OJ L 119/1) 4 May. Available from: https://eur-lex.europa.eu/legalcontent/EN/TXT/PDF/?uri=CELEX:32016R0679\&from=EN [Accessed 19 September 2018].

3 Directive 95/46/EC of the European Parliament and of the Council of 24 October 1995 on the protection of individuals with regard to the processing of personal data and on the free movement of such data. Official Journal of the European Union (OJ L 281/31) 23 November. Available from: https://eur-lex.europa.eu/legal-content/EN/TXT/PDF/?uri= CELEX:31995L0046\&from=EN [Accessed 19 September 2018]. 
the source, which is not available to the public. Data controllers nowadays collect personal data for different purposes and in different extent with different categories of personal data for each individual purpose or simply use provided personal data for different (compatible) purposes. The right of access by data subject enables to understand the internal business model of data controllers. Disclosure of business model encompasses risks not only connected with violation of the GDPR provisions, but also with competition power or reputation of data controllers.

Second, the paper discusses the issue based on the data protection legislation and its possible conflict with intellectual property (hereinafter "IP") law in particular with copyright legislation. Hence, while there is developed legal regime based on case law about the conflict between copyright or trade marks on one hand and data protection on the other hand, these cases ${ }^{4}$ refer to access to information and personal data about the infringers of IP rights of right holders. This kind of access to personal data is based on IP law and national civil law rules, protecting the right holders and is therefore different from data subject's right of access based on data protection legislation.

Third, the paper does not intend to open question of the information concept of law, what is information and data. ${ }^{5}$ The terminology used in the paper simply follows the GDPR terminology. Out of the scope of this paper is also the scope of personal data (and information as it is required in Article 15 (1) GDPR) which are eligible to be open to data subjects on the basis of the right of access. In this context, analogy with the right to data portability could be used, the data portability right should portpersonal data which concern data subjects and data which were provided by data subjects to data controllers. ${ }^{6}$ However, the right of access covers in Article 15 (1) of GDPR personal data concerning data subject. It could be argued that the access right encompasses wider scope of personal

4 See e.g. Judgment of 6 November 2003, Bodil Lindqvist, C-101/01, EU:C:2003:596, paragraphs 82 and 84; Judgment of 29 January 2008 Productores de Música de España (Promusicae) v. Telefónica de España SAU, C-275/06, EU:C:2008:54, paragraph 58; Judgment of the Court of 24 November 2011 Scarlet Extended SA v. Société belge des auteurs, compositeurs et éditeurs SCRL (SABAM), C-70/10, EU:C:2011:771, paragraph 50.

5 Bygrave, L. A. (2015) Information Concepts in Law: Generic Dreams and Definitional Daylight. Oxford Journal of Legal Studies. 35, (1), pp. 91-120. Available from: http://ojls. oxfordjournals.org/content/35/1/91 [Accessed 19 September 2018]; Polčák, R. (2016) Informace a data $\mathrm{v}$ právu. Revue pro právo a technologie, 7 (13), pp. 67-91. Available from: https://journals.muni.cz/revue/article/view/4946 [Accessed 19 September 2018].

6 Compare with Art. 20 (1) of the GDPR. 
data than the right to data portability. The Article 29 Working Party, Guidance on the right to data portability ${ }^{7}$ recognised following categories of personal data being eligible to be ported:

"raw data processed by a smart meter or other types of connected objects, activity logs, history of website usage or search activities."

Data created by data controllers (which the Article 29 Working Party called "inferred data" and "derived data", e.g. personalisation or recommendation process for data subjects) are outside the right of data portability but possibly eligible for the right of access.

Finally, the right of access to personal data is a key principle of data protection framework as it permits individuals to exercise control over their data in order to check accuracy and lawfulness of data processing performed by data controllers. Consequently, this right is a prerequisite for exercising the other rights of data subject, e.g. to obtain the rectification, erasure or blocking of her/his personal data.

There are two objectives referred to in this paper. In the first place, it describes the legislative development of the right of access at the EU level in connection with copyright. In the second place, it discusses compatibility of the access right to the copy of personal data with its copyright protection.

\section{RIGHT OF ACCESS IN LEGISLATIVE DEVELOPMENT}

The GDPR entered into force on 25 May 2018. It replaced the DPD in force from 13 December 1995. Both legal acts define the principal rights of data subjects and both recognised the right of access by the data subject. The DPD acknowledged the right of access in Article 12 (a) and the GDPR stipulates the right of access in Article 15. Providing brief legislative history of the right of access of data subject is important for this article in order to interpret its compatibility with the terms IP and copyright.

The legislative development of the right of access in the EU was introduced 18 years after adopting the DPD. In January 2012, the European Commission introduced a new legislative proposal ${ }^{8}$ and on 11 June 2015,

Article 29 Working Party. (2016) Guidelines on the right "to data portability". 16/EN WP 242 rev.01. Brussels: Directorate $C$ of the European Commission, pp. 9-10. Available from: http://ec.europa.eu/newsroom/article29/item-detail.cfm?item_id=611233 [Accessed 19 September 2018]. 
the Council of the EU published the amended version of the proposal. ${ }^{9}$ The paragraphs of the Council's version which are relevant for the scope of this paper were proposed in Article 15 (1b) and (2a) as follows:

"(1b) On request and without an excessive charge, the controller shall provide a copy of the personal data undergoing processing to the data subject."

“(2a) The right to obtain a copy referred to in paragraph $1 b$ (...) shall not apply where such copy cannot be provided without disclosing personal data of other data subjects or confidential data of the controller. Furthermore, this right shall not apply if disclosing personal data would infringe intellectual property rights in relation to processing of those personal data."

The Article 15 and paragraphs (3) and (4) of the GDPR currently in force set forth the form and restriction of the right of access by the data subject as follows:

"3. The controller shall provide a copy of the personal data undergoing processing. For any further copies requested by the data subject, the controller may charge a reasonable fee based on administrative costs. Where the data subject makes the request by electronic means, and unless otherwise requested by the data subject, the information shall be provided in a commonly used electronic form."

"4. The right to obtain a copy referred to in paragraph 3 shall not adversely affect the rights and freedoms of others."

With regard to development of the copy of personal data currently used in the GDPR, the draft of the Article $15(1 b)$ above referred to the form of the controller's response on the right of access request as copy of the personal data undergoing processing, which represented a different approach compared to the wording of the DPD (communication

8 European Commission. (2012) Proposal for the Regulation of the European Parliament and of the Council on the protection of individuals with regard to the processing of personal data and on the free movement of such data' (General Data Protection Regulation). COM(2012) 11 final. Available from: http://www.europarl.europa.eu/RegData/docs_autres_institutions/ commission_europeenne/com/2012/0011/COM_COM(2012)0011_EN.pdf 19 September 2018].

9 Council of the European Union. Proposal for the Regulation of the European Parliament and of the Council on the protection of individuals with regard to the processing of personal data and on the free movement of such data' (General Data Protection Regulation). ST-9565-2015-INIT. Available from: http://data.consilium.europa.eu/doc/document/ST-9565-2015-INIT/en/pdf. 
in an intelligible form) and the Commission's GDPR proposal wording (communication of the personal data undergoing processing).

With respect to the violation of rights and freedoms of others, the paragraph (2a) above enumerated in the normative part of the proposal which rights and freedoms may be affected the right of access by data subject. The paragraph (2a) provided that the right does not apply if disclosing personal data would infringe IP in relation to processing of those personal data. It is important to stress that paragraph (2a) did not specify whose IP rights (data controllers, others or data subjects) might be violated. However, the Article 15 (4) of the GDPR is more general and limited because relevant areas of law are not explicitly named (at least not in the normative provisions of the GDPR) and it refers only to the rights and freedoms of others. Therefore, it might be concluded that the GDPR does not provide any possibility for data controllers to deny access to personal data because of the infringement of their copyright. Similarly, the Article 13 (1) (g) of DPD limited the right of access with protection rights and freedoms of data subject and others. ${ }^{10}$ The corresponding Recital 63 to the Article 15 (4) of the GDPR sets:

"That right should not adversely affect the rights or freedoms of others, including trade secrets or intellectual property and in particular the copyright protecting the software."

These rights need to be considered by data controller before the copy is provided to the data subject, but this Recital also stipulates that

"the result of those considerations should not be refusal to provide all information to the data subject."

The issues of (in)compatibility with copyright of other parties than data controllers with the impact of limiting the right of access is discussed further from the point of quantity and quality of personal data that should be provided in the copy.

10 Article $13(1)$ DPD: "Member States may adopt legislative measures to restrict the scope of the obligations and rights provided for in Articles 6(1), 10, $11(1), 12$ and 21 when such a restriction constitutes a necessary measure to safeguard: $[. ..] \mathrm{g}$ ) the protection of the data subject or of the rights and freedoms of others." 


\section{COPYRIGHT PROTECTION OF PERSONAL DATA}

In order to answer question about copyright protection of personal data as such, the question of data controllers' property right over obtained personal data must be addressed. The response to this question has implications for the quantity and quality of personal and non-personal data $^{11}$, which have to be provided by data controllers in copy.

The Technical report prepared by the European Commission's in-house science service sums up that the Database Directive ${ }^{12}$ gives

"some limited property rights to data collectors, inspired by copyright but

limited in scope by ECJ jurisprudence"13

and that the GDPR gives some specific rights to data subjects, but refrains from defining a residual ownership in personal data.

The authors of the Technical report argue that residual rights ${ }^{14}$, which are not included in the specific rights of the GDPR (e.g. right of access, right to data portability, lawfulness of the processing of personal data), accrue ${ }^{15}$ to the data controller. In other words, if the ownership of personal data attributed to data subject is not specifically granted in the GDPR, the ownership right to the processed data is assigned to the data controllers. ${ }^{16}$ However, the report sets forth also a counter-argument that "privacy is a basic human right that cannot be alienated"17 in the meaning that natural persons possess the non-tradable rights specified in our context in the GDPR which

11 Non-personal data for the purpose of this article are understood as data which are accompanying the personal data as it is requested in the Article 15(1) of the GDPR, e.g. purpose of processing, recipients to whom data are disclosed, explanation about the source of data or storage period.

12 Directive 96/9/EC of the European Parliament and of the Council of 11 March 1996 on the legal protection of databases. Official Journal of the European Union (OJ L 77/20) 27 March. Available from: https://eur-lex.europa.eu/legal-content/EN/TXT/PDF/?uri= CELEX:31996L0009\&from=EN [Accessed 19 September 2018].

13 Compared with European Commission. (2017) JRC Technical Report. The economics of ownership, access and trade in digital data. JRC Digital Economy Working Paper 2017-01. JRC104756. p. 18. Available from: https://ec.europa.eu/jrc/sites/jrcsh/files/jrc104756.pdf [Accessed 19 September 2018].

14 Op. cit., p. 17. Residual rights are defined in the report in the context of the economic literature on property rights "as the rights that remain unspecific after specific rights have been assigned to the other parties."

15 Ibid

16 Op. cit., p. 18. The technical report argues: "Exclusive data ownership thereby becomes a de facto right: I have the data and can effectively prevent others from accessing the data, therefore I am the owner of all residual rights not explicitly assigned away to other parties through specific legal or contractual rights." 
"reduce whatever rights the data collector has as a creator of a database of personal data." 18

Distinguishing between residual rights of data controllers and rights of data subjects explicitly granted by law, authors of the Report described reality of the legal situation created by the GDPR. The de facto ownership of personal data by data controllers who can prevent data subjects from accessing their personal data increased the potential harm to data subjects and disproportionate violation with their human rights without even being aware of violation of their rights.

Zech brings to the discussion about legal ownership of informational aspects of personality an analytical perspective. ${ }^{19}$ He speaks about three layers of information - semantic, syntactic and structural. He explains that:

"Informational aspects of personality can be data, pictures, voice recordings or genetic information. Such information can either be defined on a semantic level (a certain fact about a certain person) or on asyntactic level (photographic pictures, voice recordings, gene sequences). Both are attributed to the original right owner on the semantic level, meaning they belong to the individual concerned." 20

It can be argued that the personal data as certain facts about natural persons are attributed to the data subject concerned.

Another question is whether the personal data as such are not protected also by copyright. ${ }^{21}$ Personal data have similar nature as the ideas, facts or mathematical concepts, which are excluded from copyright protection. In general, it is doubtful whether the personal data on a semantic level

17 Op. cit., p. 16.; Judgement of 17 July 2014, YS v. Minister voor Immigratie, Integratie en Asiel, C-141/12, and Minister voor Immigratie, Integratie en Asiel v. M.S, C-372/12, EU:C:2014:2081. paragraph 54 confirms that provisions of DPD "in so far as they govern the processing of personal data liable to infringe fundamental freedoms, in particular the right to privacy, must necessarily be interpreted in the light of fundamental rights [...]."

18 European Commission. (2017) JRC Technical Report. The economics of ownership, access and trade in digital data. JRC Digital Economy Working Paper 2017-01. JRC104756. p. 16. Available from: https://ec.europa.eu/jrc/sites/jrcsh/files/jrc104756.pdf [Accessed 19 September 2018].

19 Zech, H. (2015) Information as Property. JIPITEC, 6, pp. 192-197. Available from: https://www.jipitec.eu/issues/jipitec-6-3-2015/4315/zech\%206\%20\%283\%29.pdf [Accessed 19 September 2018].

20 Op. cit., pp. 195-196.

${ }^{21}$ Article 9 (2) of the Trade-Related Aspects of Intellectual Property Rights (TRIPS), 15 April 1994. Available from: https://www.wto.org/english/docs_e/legal_e/27-trips_01_e.htm [Accessed 19 September 2018] says: "Copyright protection shall extend to expressions and not to ideas, procedures, methods of operation or mathematical concepts as such." 
could be considered as literary work in the sense of qualifying for copyright protection, because they are usually insubstantial to be classified as a result of intellectual effort or usually have no degree of originality. Zech considers copyrighted information as syntactic information such as pictures or video showing data subjects, because copyright protects expressions "as opposed to the free content (ideas) which qualifies as semantic information."22 The Technical report mentioned above came to a similar conclusion that data are not protected by copyright. ${ }^{23}$

According to Zech, the third layer represents the information contained in a physical carrier, such as CD or printed books. ${ }^{24}$ Structural level refers to real property right of physical object, which is owned by the holder of this carrier. The electronic or printed copy of the personal data undergoing processing could be classified as real property right owned by the holder of the copy. Based on the circumstances, the holder might be data controller or data subject. The Article 15 (3) of the GDPR obliges data controllers to use processed personal data and create copy as an object on syntactic level and provide it to the data subject as a physical object. Understanding the copy created on the basis of the right of access in this context is a core requirement in order to discuss the copy as a subject matter of copyright protection.

To sum up, the human rights argument, in connection with Zech's three-level information model, could lead to the conclusion that personal data belong to data subject or in other words are intangible property of an individual person to whom they concern. However, the explicit recognition of the property (ownership) of personal data as such is missing in the EU legal framework. This grey area may be misused by data controllers if they try to reduce the number of personal data listed in the copy in order to restrict the overall picture about processed personal data $^{25}$ and consequently the right of access of data subject could be limited.

22 Zech, H. (2015) Information as Property. JIPITEC, 6, p. 196. Available from: https://www. jipitec.eu/issues/jipitec-6-3-2015/4315/zech\%206\%20\%283\%29.pdf [Accessed 19 September 2018].

23 European Commission. (2017) JRC Technical Report. The economics of ownership, access and trade in digital data. JRC Digital Economy Working Paper 2017-01. JRC104756. p. 8. Available from: https://ec.europa.eu/jrc/sites/jrcsh/files/jrc104756.pdf [Accessed 19 September 2018].

24 Zech, H. (2015) Information as Property. JIPITEC, 6, p. 192. Available from: https://www. jipitec.eu/issues/jipitec-6-3-2015/4315/zech\%206\%20\%283\%29.pdf [Accessed 19 September 2018].

25 E.g. in cases when data controller is not able to justify the lawfulness and purpose of personal data processing. 
In terms of copyright protection, there is probably no legal argument for data controllers to refuse to provide a copy because of copyright infringement of personal data on the semantic level. However, in case of pictures or videos of data subjects, data controllers have to determine whether the copyright holder is data subject or someone else. If the picture was provided to data controller by data subject who is the author of the picture, the access right to the picture has to be provided. In case the author is not a data subject (e.g. the picture was uploaded on the social network by third person and data subject was tagged on the picture), it is not acknowledged by the GDPR if data controllers have obligation to acquire IP rights from third parties in order to provide right of access to data subjects.

\section{COPY - PHYSICAL OBJECT AS A SUBJECT MATTER OF COPYRIGHT}

This part describes a process of creating a copy of personal data according to the GDPR as a starting point for the discussion about a copy (physical object) as a subject matter protected by copyright.

First of all, the GDPR is applicable only to those controllers, who are processing personal data. These controllers process personal data, which are structured to specific criteria relating to individuals ${ }^{26}$ in a filing system. The concept of a filing system in the DPD/GDPR is unique for the data protection and the definition is not comparable to generally known concept of database or electronic file. Filing system is a structural set of personal data accessible based on specific criteria (centralised, decentralised or distributed on geographical or functional basis). ${ }^{27}$ The filing system contains structured and easily accessible personal data.

After receiving a request for access, the data controllers need to search for processed personal data of the requested natural person in filing systems, summarise matched data and provide copy of the data to the data subject. Carey added that

\footnotetext{
${ }^{26}$ See Recital 15 and 27 of the DPD, Recital 15 of the GDPR.

27 See Article 2 (c) of the DPD, Article 4 (6) of the GDPR.
} 
"when dealing with requests for access, data controllers are obliged to provide the information constituting the personal data, rather than the documents containing the data."28

Similarly, CJEU in its decision in YS v. Minister voor Immigratie and others $^{29}$ explains that the form of communication on the basis of Article 12 (a) DPD is not the right to obtain a copy of the document or original file containing the data. However, data controller could decide to provide copy of the document or the original file and the CJEU concluded that in this case, other information or data in such copy must be redacted. It is important to add that each copy needs to be obligatorily accompanied with other data ${ }^{30}$ e.g. about the purpose of processing, recipients to whom the data are disclosed, explanation about the source of data or explanation of the logic involved in automatic processing of data, storage period etc. Moreover, provided information must be concise, intelligible, using clear and plain language etc. ${ }^{31}$

The result of the right of access in the GDPR has two ways of interpretation: copy created as a summary of personal data or copy of original document with personal data. ${ }^{32}$

The data protection law obliges the data controllers to implement the right of access by providing copy, which fulfils all requirements described above. However, the question is whether copy which fulfils all GDPR's requirements, could be protected by copyright. On the contrary, it is not possible to argue that all future copies of the summary of processed personal data are automatically excluded from the copyright protection. Otherwise, there is no need for the Article 15 (4) in the GDPR. Moreover, Recital 63 of the GDPR requires that the qualifying criteria for the IP

28 Carey, P. (2009) Data Protection, A Practical Guide to UK and EU Law. 3rd ed. New York: Oxford University Press, p 134.

29 Judgement of 17 July 2014, YS v. Minister voor Immigratie, Integratie en Asiel, C-141/12, and Minister voor Immigratie, Integratie en Asiel v. M.S, C-372/12, EU:C:2014:2081, paragraph 58.

30 See Article 15 (1) of the GDPR.

31 See Article 12 (1) of the GDPR.

32 Due to the limited scope of the Article, second form - a copy of the document or original file - is not being further discussed as possible subject matter of copyright protection. However, there might be cases when copy of the whole document is provided to data subject, e.g. list of marks, health documentation, emails. Such document may be protected by copyright as literary or artistic work. Therefore, before the copy of the document is provided to data subject, the controller must consider the authorship of the work. It is also possible that the author of the document is data subject or the third party. In latter case, the data controllers need to acquire approval to reproduce and distribute the work to data subjects. 
protection of others needs to be assessed on the case by case basis by data controllers before the copy is provided to data subject. Therefore, discussion below provides arguments about copy being subject matter protected also by copyright.

\subsection{COPY PER SE PROTECTED BY COPYRIGHT}

Subject matter protected by copyright is the work created by the author. Švidroň summarised that the criteria for the work were as follows:

"1. literary, scientific or artistic expression of the work;

\section{2. intellectual creation;}

3. the work is objectively expressed, which enables repeating sensual perception." ${ }^{33}$

Applying the above criteria to a copy of personal data, it could be considered:

Ad. 1: Copy of personal data might be a list of structured personal data, which provides information about the content of their life to data subject (e.g. copy of personal data from social platform wall). Such copy could be identified as literary work by data controller. The threshold necessary to qualify copy as a copyrighted work is its originality in creation of its author/data controller.

Ad. 2: Data controller (usually a commercial entity) can be an author or right holder of such copy because of her/his input in terms of creativity, in finding, selecting, organising and presenting relevant personal data forming a summary of personal data for each data subject requesting access. Along this line of reasoning, the Recital 63 does not allow to refuse to provide all information to the data subject. In practice this means that data controllers are always obliged to create (original) copy with some personal data or information. The data controllers may choose from different techniques or use of computer software to adopt the copy. Each copy provided to data subject from data controller could be different in a sense of original organisation/structure/arrangement or format

33 Švidroň, J. (2000) Základy práva duševného vlastníctva. Bratislava: JUGA, pp. 69-72. Compare also with the judgement of 16 July 2009, Infopaq International A/S v. Danske Dagblades Forening, C-5/08, EU:C:2009:465, paragraphs 34-50; Judgement of 1 December 2011, Eva-Maria Painer v. Standard VerlagsGmbH, C-145/10, EU:C:2011:798, paragraph 87; Judgement of 22 December 2010, Bezpečnostní softwarová asociace - Svaz softwarové ochrany v. Ministerstvo kultury, C-393/09, EU:C:2010:816, paragraphs 45-49. 
of the order/layout of personal data and other information. The formative freedom of data controller put in copy might represent his "personal touch". ${ }^{34}$ Under the given scenario, the copy themselves as a subject matter of copyright protection could be protected as a collective work or a database. The Article 2 (5) of the Berne Convention ${ }^{35}$ could protect copy as a compilation. However, personal data are not protected by copyright as literary or artistic works as it was argued in part 3 of this paper, therefore copy as such seems not to be protected as the compilation. The Berne Convention sets also criterion that the selection and arrangement of compilation's content constitutes intellectual creation. Compare to the Article 3 (1) of the Database Directive the required criterions for copyright protection are more general. The database is protected by copyright if the selection or arrangement of content of database constitutes the author's own intellectual creation. Moreover, the copyright protection of database does not extent to the content. If the copy per se could be protected by copyright, such protection is likely to be stipulated by the database protection which is analysed in part 4.2 of this paper.

Ad. 3: Article 15 (3) of the GDPR requires to provide a copy in writing or by electronic means. Therefore, such copy is objectively expressed for sensual perception.

In principle, copy of personal data (understood in a sense of the structure of data) created on the basis of the right of access in the GDPR could be protected by copyright. This conclusion was not excluded by the CJEU, which ruled that

"the format of SAS Institute's data files might be protected, as works, by copyright under Directive 2001/29 if they are their author's own intellectual creation."

34 Compare with the judgement of 1 December 2011, Eva-Maria Painer v. Standard VerlagsGmbH, C-145/10, EU:C:2011:798, paragraphs 87-94.

35 The Article 2 (5) of the Berne Convention for the Protection off Literary and Artistic Works says: "Collections of literary or artistic works such as encyclopedias and anthologies which, by reason of the selection and arrangement of their contents, constitute intellectual creations shall be protected as such, without prejudice to the copyright in each of the works forming part of such collections." Berne Convention for the Protection off Literary and Artistic Works, 19 November 1984. Available from: http://www.wipo.int/wipolex/en/treaties/text.jsp?file_id=283693 [Accessed 19 September 2018]

36 Judgement of 2 May 2012, SAS INSTITUTE v. World Programming Ltd, C-406/10, EU:C:2012:259, paragraph 45. 
Another theoretical conflict between IP and data protection identifies Margaret Ann Wilkinson whose approach regards the Canadian jurisdiction. She argued that the right of access and subsequent right to obtain rectification of personal data may interfere with the copyright interests of the creators of the records because only creators have the right to make any change to their work. She recognises the moral right of the creator to the integrity of the work. ${ }^{37}$ Developing further the moral right of the creator to the integrity of the work, argument could be found in the Article 29 Working Party Guidance on the right to data portability which explains:

"The right to data portability is not a right for an individual to misuse the information in a way that could be qualified as an unfair practice or that would constitute a violation of intellectual property rights. ${ }^{138}$

That would imply that also in the EU if a copy is considered to be protected by copyright, such protection could limit the right of data subject to rectification or erasure (known as right to be forgotten) of personal data because data controllers have moral rights attributed to the copy e.g. to object modification or derogation of their work. ${ }^{39}$

Further, the obligation to provide copy under the GDPR could be seen as a reproduction of a protected work existing in the filing system of data controller and creating another work from the filing system. The accuracy of this argument might be supported by the CJEU, 2009, Infopaq International $A / S$ v. Danske Dagblades Forening decision. The CJEU discussed whether the reproduction right extended to the reproduction of 11 words extracts. The Court concluded that the 11 consecutive words constitute reproduction under the meaning of Article 2 of Directive 2001/29/EC, but the determination if elements of reproduction of the words expressed author's own intellectual creation is kept for the decision of national court. Otherwise, there has been no case law to date regarding this issue, which

${ }^{37}$ Wilkinson, M.A. (2001) The Copyright Regime and Data Protection Legislation. In: Ysolde Gendreau (ed.). Law Publications. Cowansville, Les Editions Yvon Blais Inc., p. 88. Available from: http://works.bepress.com/ma_wilkinson/17/ [Accessed 19 September 2018].

38 Article 29 Working Party. (2016) Guidelines on the right "to data portability". 16/EN WP 242 rev.01. Brussels: Directorate C of the European Commission, p. 12. Available from: http://ec. europa.eu/newsroom/article29/item-detail.cfm?item_id=611233 [Accessed 19 September 2018].

39 See Article 6bis (1) Berne Convention for Protection off Literary and Artistic Works, 19 November 1984. Available from: http://www.wipo.int/wipolex/en/treaties/text.jsp?file_id $=283693$ [Accessed 19 September 2018]. 
will exclude conclusion that copy of personal data per se is not eligible subject matter of copyright protection.

However, state-of-the-art technology makes copyright protection of the copy more theoretical question. Technological development of the Internet enables creation of copy without any human intervention (as computer-generated works). Therefore, data controller could not claim authorship in case a copy is generated by the automatic computer program. This situation might in some jurisdictions conflict with the definition of authorship in copyright protection. ${ }^{40}$ Moreover, copy of similar structure/ arrangement is usually provided to each data subject, whose data are processed in the filing system for reasons of simplifying the creative process of the copy from data controllers' point of view. Such copy reflects almost no intellectual effort or original creativity of data controller. Finally, there is a difference in the purpose of copyright and right of access. The aim of copyright is to advance "authorial autonomy and cultural diversity." On the other hand, the copy under the GDPR is created by the data controller for the benefit of one individual data subject with the aim to provide her/him control which personal data are processed by the data controller. Under the described circumstances, copy per se will not qualify for copyright protection.

To sum up, the European Commission Staff Working document dealing with machine-generated and industrial data states that these data

"do not benefit from protection by other intellectual property rights as they are deemed not to be the result of an intellectual effort. Results of data integration, analytics, etc. can be protected, on the other hand, as a result of a protection given to the intellectual effort made into the design of the data integration process or the analytics algorithm (software)."

40 See Article 13 (1) Slovak Copyright Act No. 185/2015 Coll., which defines Author as natural person who created work. On the other hand, Article 9 (3) UK Copyright, Designs and Patents Act 1988 sets that: "case literary, dramatic, musical artistic work which is computergenerated, author shall be taken to be person whom arrangements necessary for creation work are undertaken." This may be programmer another person. Similarly, Guadamuz, A. (2017) Artificial intelligence and copyright. [online] WIPO Magazine. Available from: http://www.wipo.int/wipo_magazine/en/2017/05/article_0003.html [Accessed 19 September 2018] presented legal opinion that: "There are two ways which copyright law can deal with works where human interaction is minimal non-existent. It can either deny copyright protection for works that have been generated computer it can attribute authorship such works to creator program."

${ }_{41}$ Goldstein, P. and Hugenholtz, B. (2010) International Copyright, Principles, Law, and Practice. 2nd ed. Oxford University Press, p. 7. 
The Articles 15 (3) and (4) of the GDPR can be understood as the legislator's intention not to determine eligibility for copyright protection for the copy per se or personal data as such, but for the intellectual effort invested into the design of the personal data integration process or software, on which computer program operates and from which the copy is generated. Consequently, in case the right holder of the computer program is the data controller, she/he could not claim that the copy is infringing her/his IP rights, because such copy is not infringing the rights or freedoms of others which is the condition set in the Article 15 (4). The right of access in the GDPR could be understood as the legal obligation to grant access or license to the requesting data subject even though the rights and freedoms of data controllers might be infringed by providing the copy of personal data to data subjects.

\title{
4.2 COPY PROTECTED AS DATABASE
}

The Database Directive in Article 1 (2) defines database as

\begin{abstract}
"a collection of independent works, data or other materials arranged in a systematic or methodical way and individually accessible by electronic or other means."
\end{abstract}

It is important to emphasize that computer software making or operating the database is not subject of the Database Directive protection. ${ }^{43}$ The Database Directive provides two types of protectioncopyright and sui generis. Databases are protected by copyright if the selection or the arrangement of content is the intellectual creation of an author himself/herself. ${ }^{44}$ Sui generis right (protecting economic investment of the maker of the database) is not copyright or other IP right. Goldstein and Hugenholtz described the sui generis right as being similar to neighbouring rights of phonogram producers and film producers. ${ }^{45}$

\footnotetext{
42 European Commission. (2017) Commission Staff Working Document free flow data and emerging issues European data economy, Accompanying document, Communication Building European data economy, SWD.(2017) 2 final. Brussels, p. 19. Available from: https://ec.europa.eu/digitalsingle-market/en/news/staff-working-document-free-flow-data-and-emerging-issueseuropean-data-economy [Accessed 19 September 2018].

43 Article 1 (3) Database Directive.

${ }^{44}$ Article 3 (1) and Recital 15 Database Directive.

45 Goldstein, P. and Hugenholtz, B. (2010) International Copyright, Principles, Law, and Practice. 2nd ed. Oxford University Press, p. 239.
} 
Maker of database must substantially invest either in obtaining, verification or presentation of the content. ${ }^{46}$

Personal data processed by data controller may qualify for the protection under the Database Directive. Data controllers usually collect and store personal data of all data subject in data files in the form of databases. The collection is classified as database when it is arranged in a systematic or methodical way and is individually accessible by electronic means. The CJEU in the decision Fixtures Marketing Ltd v. Organismos prognostikon agonon podosfairou $A E(O P A P)^{47}$ specifies that the term "database" is defined in terms of its function, which distinguishes a database from other collection of materials providing information. The function of database contained technical means such as electronic, electromagnetic or electro-optical processes, index, a table of contents, or a particular plan or method of classification, which process the data of which the database consists and allow the retrieval of any independent material contained within it. ${ }^{48}$ We are of the opinion that copy created on the basis of Article 15 (3) of the GDPR could be treated as reproduction of original electronic database or extraction of a part of database, because without the described functionality of electronic database, the data controller is not capable to organise personal data for the accessibility by data subject.

However, the electronic databases of personal data will usually not qualify for the copyright protection of the Database Directive, because the criteria of author's own selection or arrangements of content of the database is not met. ${ }^{49}$ This conclusion is confirmed by the CJEU decision in Football Dataco Ltd and Others against Yahoo! UK Ltd and Others. ${ }^{50}$

46 See Article 7 (1) Database Directive.

47 Judgement 9 November 2004, Fixtures Marketing Ltd v. Organismos prognostikon agonon podosfairou AE (OPAP), C-444/02, EU:C:2004:697, paragraphs 29-32.

48 Functional criterion sui generis right further described CJEU Fixtures Marketing Decision paragraph 43 as: "expression 'investment [...] verification [...] contents' database must be understood to refer to resources used, with view to ensuring reliability information contained that database, to monitor accuracy materials collected when database was created and during its operation. expression 'investment [...] presentation contents' database concerns, for its part, resources used for purpose giving database its function processing information, that is to say those used for systematic methodical arrangement materials contained that database and organisation their individual accessibility."

49 See European Commission. (2016) Legal study Ownership and Access to Data. European Commission DG Communications Networks, Content \& Technology, Osborne Clarke LL.P, p. 13. Available from: https://publications.europa.eu/en/publication-detail/-/publication/d0b ec895-b603-11e6-9e3c-01aa75ed71a1 [Accessed 19 September 2018].

50 Judgement 1 March 2012, Football Dataco Ltd and others against Yahoo! UK and others, C-604/10, EU:C:2012:115. 
The CJEU ruled that the criterion of originality (as a stamp of its personal touch) is not met

"when the setting up of the database is dictated by technical considerations, rules or constraints which leave no room for creative freedom." ${ }^{11}$

The eligibility for this criterion by the original database of data controller may not be met and the same may analogically apply for the copy of processed personal data. The level of originality required for selection or arrangement of content of databases (structure of database) is the same as it is required for the copy per se discussed in the previous 4.1 part of the paper.

The sui generis right is the right intended for protection of investment in obtaining, verifying or presenting the data or the content of database. ${ }^{52}$ The main defining criterion for the protection of this kind of database is an investment (qualitative or quantitative and substantial). The substantial investment is assessed on the basis of human, financial or technical resources necessary for obtaining, verification or presentation of the content of database. The data controller, who is processing personal data in the filing system, might be eligible for sui generis protection of his/her database. In this case, the data controller has the right for extraction (as reproduction) and re-utilisation (understand as making available to the public) of the whole or a substantial part of database. Creating copy of personal data from database protected by sui generis right by data controller (maker of database) is extraction of the database. However, the right of access on the basis of Article 15(3) of the GDPR does not deprive the maker of database of the sui generis rights because the act of extraction is not adversely affecting rights and freedoms of third parties only the rights attributed to the maker of database. Article $15(4)$ of the GDPR limits the right of access only in case the right to obtain copy affects the rights and freedoms of others.

Even though, the sui generis right of the maker of database is in conflict with the right of access authorised by the GDPR, the sui generis right could not stand in a way of the access right under the GDPR.

\footnotetext{
51 Op. cit., paragraph 39.

${ }^{52}$ Compare with Recital 40 Database Directive.
} 


\subsection{ACCESS RIGHT INFLUENCED BY COMPUTER PROGRAM PROTECTION}

The Computer Program Directive ${ }^{53}$ protects only the expression ${ }^{54}$ of computer program (software). Since the conflict between the copyright protection of software in the context of protecting rights of others (not data controllers) and the right of access is explicitly mentioned in the Recital 63 of the GDPR, the software protection should be incompatible with the copy of personal data. The next part discusses if and to what extent is the access to personal data conflicting with the copyright protection of software.

As it is suggested in the Paragraph 4.1 above, protection of the copy is based on the copyright protection of software, on which computer program operates or from which the copy is generated and accessible. There are at least two scenarios of possible clash of the two rights.

Firstly, in practice, the right holder (author) of the computer program may decide not to provide copy because of his/her exclusive rightreproduction, defined in article 4 (1) (a) of the Computer Program Directive as:

"the permanent or temporary reproduction of a computer program by any means and in any form, in part or in whole; in so far as loading, displaying, running, transmission or storage of the computer program necessitate such reproduction, such acts shall be subject to authorisation by the right holder."

E.g. in machine learning scenario, the data controllers may face an issue how to provide all available personal data, which are processed, about the data subjects together with the logic involved in such processing. ${ }^{55}$ The issue may be caused by lack of knowledge of data controllers about processing operation ${ }^{56}$ and the easiest way how to fulfil the right of access

53 Directive 2009/24/EC European Parliament and Council 23 April 2009 legal protection computer programs. Official Journal European Union (OJ L 111/16) 5 May. Available from: https://eur-lex.europa.eu/legal-content/EN/TXT/PDF/?uri=CELEX:32009L0024\&from=EN [Accessed 19 September 2018].

54 See Article 1 (2) Computer Program Directive.

55 Article 15 (1) (h) GDPR.

56 See Jánošík, J. (2017) Transparency machine-learning algorithms is double-edged sword. [online] welivesecurity. Available from: https://www.welivesecurity.com/2017/11/13/transparencymachine-learning-algorithms/ [Accessed 19 September 2018], where it is stated: "Yes, other citizens' rights introduced expanded GDPR, like right to object to profiling, right to obtain copy personal data gathered, right to be forgotten - can all be costly to comply with. But many companies are finding themselves incapable providing an explanation results their personal data processing. And worse - they often simply can't figure out how to comply with this GDPR-imposed obligation." 
is to provide a copy of algorithm concerned. Creating such copy may qualify as exclusive act of partial reproduction of computer program. ${ }^{57}$

Second scenario may arise, if data controllers provide the electronic copy (consisting only of personal data) in a special format of software, which is not accessible to data subjects. ${ }^{58}$ Consequently, copy cannot be opened by Microsoft Excel or Word installed in majority of computers owned by data subjects. In order to gain access to the copy, data subjects need to buy another computer program, which may be sold by data controllers themselves. In case data subjects do not have the right to use this software the possibility to open copy is refused on grounds of copyright protection of computer program.

The right of access in data protection may conflict with the Computer Program Directive if third parties' rights would be infringed. Both above-described scenarios might be considered as marginal cases, but they constitute possible arguments for data controllers, when they intend to limit access to personal data.

\section{BALANCING EXCLUSIVE RIGHTS}

The discussion in previous parts of this article focuses on possible conflicts between right of access and copyright. Both rights encompass values for their beneficiaries. They are recognised and well established in their legal frameworks and in the Charter of Fundamental Rights of the European Union (hereinafter "Charter"). ${ }^{59}$ In case of conflict of rights, Article 15 (4) of the GDPR obliges data controllers to balance these two fundamental rights with the rights and freedoms of others.

The task of balancing rights requires comparing/weighing opposing interests and deciding, which prevails. The Recital 63 of the GDPR permit

57 SeeJudgement 2 May 2012, SAS INSTITUTE v. World Programming Ltd, C-406/10, EU:C:2012:259, paragraph 43: "[...] should be made clear that, third party were to procure part source code object code relating to programming language to format data files used computer program, and that party were to create, with aid that code, similar elements its own computer program, that conduct would be liable to constitute partial reproduction within meaning Article 4 (a) Directive 91/250."

58 This scenario may contradict with Article 15 (3) GDPR which requires that "information shall be provided commonly used electronic form." However, situation when data subjects could not afford to buy even commonly used software because remuneration software copyright holders. GDPR should extent requirement to commonly used and freely obtainable software order to strengthen its technological neutrality.

59 See Article 17 (2) Charter Fundamental Rights European Union, 26 October 2012, (2012/C 326/02) Available from: https://eur-lex.europa.eu/legal-content/EN/TXT/PDF/?uri=CELEX: 12012P/TXT\&from=EN [Accessed 19 September 2018], which guaranteed protection of IP and second sentence Article 8 (2) recognized everyone's right access to data which has been collected concerning him her, and right to have it rectified. 
to exercise the power of balancing rights to data controllers. Data controllers act as gatekeepers, who decide on the quantity and quality of personal data provided to the data subject. This is a "tool" chosen by the legislator in data protection framework for determining the rights and freedoms of data subjects or third parties. However, each balancing of the interests and rights involved will depend on the circumstances of an individual case and needs to be exercised on case by case basis.

The practical example of the balancing exercise is described in the Opinion of Advocate General connected with the Article (7) (f) of the DPD. ${ }^{60}$ The balancing exercise was weighing, whether to provide personal data of taxi driver to injured party from the police administrative decision for issuing civil proceeding by injured party. The Advocate General Bobek suggested balancing nature and sensitivity of the requested data (their degree of publicity, age of the data subject) and the gravity of the offence committed.

As it may be understood from the above example, balancing or weighing of competing interests by data controllers is a challenging requirement. ${ }^{61}$ The discussion about copy as a subject matter of copyright protection shows that there are relatively rare circumstances, when the copy meets requirements of copyright protection. The GDPR provides data controllers with the option of refusing the full access to the processed personal data in a form of copy because of the rights of others. Consequently, the lawfulness of refusal is difficult to be verified by data subjects. The ability to neutrally weigh all interests at stake is vested in Data Protection Authorities, who might need to become also copyright law experts.

\section{CONCLUSION}

The subject matter of Article 15 (3) of the GDPR - copy of personal data may infringe copyright protection of the data controller who is usually the right holder/author of the copy. According to our findings, the conflict with copyright protection could not deprive the data subject of the right

60 Opinion Advocate General 26 January 2017, Valsts policijas Rīgas reǵiona pārvaldes Kārtības policijas pārvalde v. Rīgas pašvaldības SIA 'Rīgas satiksme', C-13/16, EU:C:2017:43, paragraphs 67-69.

61 They need to compare positive benefits and effect restrictive act with its negative effect fundamental right. Positive interest third parties might be seen protecting their business models when processing and trading with personal data. Harm caused to data subject might have implication to data subject private life e.g. automated decision made algorithm could lead to negative legal effect data subject personal life. 
of access. The copy of personal data is not infringing the rights or freedoms of others which is the limitation of the right of access sets in the Article 15 (4) of the GDPR. The proper and frequent application of the right of access by data subjects will increase interplay between copy of processed personal data and copyright protection and should prove this conclusion.

From data controllers' point of view, copyright protection of works of others ${ }^{62}$ represents a simple argument how to limit the quality and quantity $^{63}$ of personal data provided on the basis of the right of access. Therefore, we are of the opinion that the copyright law will prevail over the right of access. Firstly, because these two rights as discussed above may be incompatible. Secondly, the data controllers are primarily responsible for balancing conflicting rights and neutral balancing exercise could only be applied by the Data Protection Authorities. Thirdly, the case law of the CJEU regarding this issue will need to be developed because the copy as a result of access right may be considered as a new element in data protection law introduced by the GDPR.

Possible solutions which will enable exercising the right of access in the form of copy without a risk of IP or copyright infringement claims are as follows:

(i) to create exception for data controllers. The exception will acknowledge providing personal data (e.g. videos or pictures) without consent of the right holder for exercising the right of access. The new exception could be limited to the use of the copy only for the private (or household) purposes of data subjects and for exercising rights of data subjects under the GDPR;

(ii) to include the obligation for data controller to provide also reasons of the refusal of providing copy which rights and freedoms of third parties were balanced by the data controller. The information about conflicting rights will increase legal certainty for data subjects. Data subjects will better assess whether the act of data controller was legitimate with consequence of smaller number of cases submitted to the Data Protection Authorities.

\footnotetext{
62 Copyright protection works others is other than copyright protection held data controller.

63 This discussion, compare with Recital 63 GDPR: "[...] result those considerations should not be refusal to provide all information to data subject [...]".
} 
The compatibility of the right of access with copyright protection of other parties poses a lot of open questions which were partially discussed in the paper, sometimes only briefly mentioned. In the near future, data subjects need to use the right of access, wait for its application by data controllers and finally case law of the CJEU will have to provide comprehensive answers.

\section{LIST OF REFERENCES}

[1] Article 29 Working Party. (2016) Guidelines on the right "to data portability". 16/EN WP 242 rev.01. Brussels: Directorate C of the European Commission. Available from: http://ec. europa.eu/newsroom/article29/item-detail.cfm?item_id=611233 [Accessed 19 September 2018].

[2] Berne Convention for the Protection off Literary and Artistic Works, 19 November 1984. Available from: http://www.wipo.int/wipolex/en/treaties/text.jsp?file_id=283693

[Accessed 19 September 2018].

[3] Bygrave, L. A. (2015) Information Concepts in Law: Generic Dreams and Definitional Daylight. Oxford Journal of Legal Studies. 35, (1), pp.91-120. Available from: http://ojls.oxfordjournals.org/content/35/1/91 [Accessed 19 September 2018].

[4] Carey, P. (2009) Data Protection, A Practical Guide to UK and EU Law. 3rd ed. New York: Oxford University Press.

[5] European Commission. (2017) Commission Staff Working Document on the free flow of data and emerging issues of the European data economy, Accompanying the document, Communication Building a European data economy, SWD. (2017) 2 final. Brussels. Available from: https://ec.europa.eu/digital-single-market/en/news/staff-working-document-freeflow-data-and-emerging-issues-european-data-economy [Accessed 19 September 2018].

[6] Copyright Act 2015, SI 185/2015. Slovak Republic. In Slovak.

[7] Copyright, Designs and Patents Act 1988 (c. 48). United Kingdom of Great Britain and Northern Ireland. London: HMSO. In English.

[8] Charter of Fundamental Rights of the European Union, 26 October 2012, (2012/C 326/02) Available from: https://eur-lex.europa.eu/legal-content/EN/TXT/PDF/?uri=CELEX:12012P /TXT\&from=EN [Accessed 19 September 2018].

[9] Directive 2009/24/EC of the European Parliament and of the Council of 23 April 2009 on the legal protection of computer programs. Official Journal of the European Union (OJ L 111/16) 5 May. Available from: https://eur-lex.europa.eu/legal-content/EN/TXT/PDF/? uri=CELEX:32009L0024\&from=EN [Accessed 19 September 2018]. 
[10] Directive 95/46/EC of the European Parliament and of the Council of 24 October 1995 on the protection of individuals with regard to the processing of personal data and on the free movement of such data. Official Journal of the European Union (OJ L 281/31) 23 November. Available from: https://eur-lex.europa.eu/legal-content/EN/TXT/PDF/?uri= CELEX:31995L0046\&from=EN [Accessed 19 September 2018].

[11] Directive 2001/29/EC of the European Parliament and of the Council of 22 May 2001 on the harmonisation of certain aspects of copyright and related rights in the information society. Official Journal of the European Union (OJ L 167/10) 22 June. Available from: https://eur-lex.europa.eu/legal-content/EN/TXT/PDF/?uri=CELEX:32001L0029\&from=EN [Accessed 19 September 2018].

[12] Directive 96/9/EC of the European Parliament and of the Council of 11 March 1996 on the legal protection of databases. Official Journal of the European Union (OJ L 77/20) 27 March. Available from: https://eur-lex.europa.eu/legal-content/EN/TXT/PDF/?uri= CELEX:31996L0009\&from=EN [Accessed 19 September 2018].

[13] Goldstein, P. and Hugenholtz, B. (2010) International Copyright, Principles, Law, and Practice. 2nd ed. Oxford University Press.

[14] Guadamuz, A. (2017) Artificial intelligence and copyright. [online] WIPO Magazine. Available from: http://www.wipo.int/wipo_magazine/en/2017/05/article_0003.html [Accessed 19 September 2018].

[15] Jánošík, J. (2017) Transparency of machine-learning algorithms is a double-edged sword. [online] welivesecurity. Available from: https://www.welivesecurity.com/2017/11/13/ transparency-machine-learning-algorithms/ [Accessed 19 September 2018].

[16] European Commission. (2017) JRC Technical Report. The economics of ownership, access and trade in digital data. JRC Digital Economy Working Paper 2017-01. JRC104756. Available from: https://ec.europa.eu/jrc/sites/jrcsh/files/jrc104756.pdf [Accessed 19 September 2018].

[17] Judgement of 16 July 2009, Infopaq International A/S v. Danske Dagblades Forening, C-5/08, EU:C:2009:465.

[18] Judgement of 1 December 2011, Eva-Maria Painer v. Standard VerlagsGmbH, C-145/10, EU:C:2011:798.

[19] Judgement of 17 July 2014, YS v. Minister voor Immigratie, Integratie en Asiel, C-141/12, and Minister voor Immigratie, Integratie en Asiel v. M.S, C-372/12, EU:C:2014:2081.

[20] Judgement of 9 November 2004, Fixtures Marketing Ltd v. Organismos prognostikon agonon podosfairou AE (OPAP), C-444/02, EU:C:2004:697. 
[21] Judgement of 2 May 2012, SAS INSTITUTE v. World Programming Ltd, C-406/10, EU:C:2012:259.

[22] Judgement of 1 March 2012, Football Dataco Ltd and others against Yahoo! UK and others, C-604/10, EU:C:2012:115.

[23] Judgement of 22 December 2010, Bezpečnostní softwarová asociace - Svaz softwarové ochrany v. Ministerstvo kultury, C-393/09, EU:C:2010:816.

[24] Judgment of 6 November 2003, Bodil Lindqvist, C-101/01, EU:C:2003:596.

[25] Judgment of 29 January 2008 Productores de Música de España (Promusicae) v. Telefónica de España SAU, C-275/06, EU:C:2008:54.

[26] Judgment of the Court of 24 November 2011 Scarlet Extended SA v. Société belge des auteurs, compositeurs et éditeurs SCRL (SABAM), C-70/10, EU:C:2011:771.

[27] European Commission. (2016) Legal study on Ownership and Access to Data. European Commission DG Communications Networks, Content \& Technology, Osborne Clarke LL.P. Available from: https://publications.europa.eu/en/publication-detail/-/publication/ d0bec895-b603-11e6-9e3c-01aa75ed71a1 [Accessed 19 September 2018].

[28] Opinion of Advocate General of 26 January 2017, Valsts policijas Rīgas regiiona pārvaldes Kārtības policijas pārvalde v. Rīgas pašvaldības SIA 'Rīgas satiksme', C-13/16, EU:C:2017:43.

[29] Polčák, R. (2016) Informace a data v právu. Revue pro právo a technologie, 7 (13), pp. 67-91. Available from: https://journals.muni.cz/revue/article/view/4946 [Accessed 19 September 2018].

[30] European Commission. (2012) Proposal for the Regulation of the European Parliament and of the Council on the protection of individuals with regard to the processing of personal data and on the free movement of such data' (General Data Protection Regulation). COM(2012) 11 final. Available from: http://www.europarl.europa.eu/RegData/docs_autres_institutions/ commission_europeenne/com/2012/0011/COM_COM(2012)0011_EN.pdf

[Accessed 19 September 2018].

[31] Council of the European Union. (2015) Proposal for the Regulation of the European Parliament and of the Council on the protection of individuals with regard to the processing of personal data and on the free movement of such data' (General Data Protection Regulation). ST-9565-2015-INIT. Available from: http://data.consilium.europa.eu/doc/document/ST9565-2015-INIT/en/pdf [Accessed 19 September 2018].

[32] Regulation (EU) 2016/679 of the European Parliament and of the Council of 27 April 2017 on the protection of natural persons with regard to the processing of personal data and 
on the free movement of such data, and repealing Directive 95/46/EC. Official Journal of the European Union (OJ L 119/1) 4 May. Available from: https://eur-lex.europa.eu/legal -content/EN/TXT/PDF/?uri=CELEX:32016R0679\&from=EN [Accessed 19 September 2018].

[33] Švidroň, J. (2000) Základy práva duševného vlastníctva. Bratislava: JUGA.

[34] Trade-Related Aspects of Intellectual Property Rights (TRIPS), 15 April 1994. Available from: https://www.wto.org/english/docs_e/legal_e/27-trips_01_e.htm [Accessed 19 September 2018].

[35] Wilkinson, M.A. (2001) The Copyright Regime and Data Protection Legislation. In: Ysolde Gendreau (ed.). Law Publications. Cowansville, Les Editions Yvon Blais Inc., pp.77-100. Available from: http://works.bepress.com/ma_wilkinson/17/ [Accessed 19 September 2018].

[36] Zech, H. (2015) Information as Property. JIPITEC, 6, pp. 192-197. Available from: https://www.jipitec.eu/issues/jipitec-6-3-2015/4315/zech\%206\%20\%283\%29.pdf [Accessed 19 September 2018]. 